Prof. Partridge, moreover, offers some wise counsel to the universities which has relevance even in the more favourable circumstances of Britain. He suggests that, in spite of obvious dangers and difficulties, the universities should, in partnership with the Commonwealth and State Governments, attempt to evolve national policies of expansion and policies which will provide for some measure of specialization in the different universities, particularly in research. It is not unreasonable, he argues, to expect that the universities should at least explore the possibility of using as rationally as possible the greater resources placed at their disposal by the State, and there is much to be gained from the point of view of academic standards by not dispersing available workers too thinly over a comparatively large number of institutions. To take the initiative in such ways would, he believes, strengthen the universities themselves and might also facilitate the change in thinking of the State Governments which he also thinks desirable for the use of Commonwealth funds and to meet national needs. What Prof. Partridge urges has some relevance to the expansion of technological education in Britain.

The paper by Prof. D. M. Myers on the Australian universities and industry is essentially a factual account of these relations during the past hundred years, which emphasizes the factors dominating the present scene, such as the dependence of the Australian economy on its primary products, the extreme concentration of the population and of secondary industries in several major centres, and the unusual position in industrial research occupied by government institutions such as the Commonwealth Scientific and Industrial Research Organization. Prof. Myers comments on the unfavourable effect on the universities of this uneven distribution of the population, with the consequent tendency to parochialism and absence of interchange of staff, and he believes that it will be a happy day, too, for Australian industry when the universities regain a proper balance in their activities and are dependent on direct grants through an appropriate body set up for the purpose rather than on the support of a government body estab. lished for definite practical objectives. Prof. Myers makes some practical suggestions for future relations between Australian universities and industry on these lines.

Prof. A. Boyce Gibson's paper on the Australian universities and public opinion makes some sound points which should be noted in Britain, though he thinks that, in general, Australian universities have more to learn about public relations from the United States than from Britain. He suggests that the universities should do more to communicate their own scale of values and that the best way to open up public opinion is to do things the use of which is apparent to people uninterested in inquiry and scholarship : in science, by increasing welfare; in arts, by raising the standards of discussion and entertainment.

Prof, R. M. Crawford, discussing postgraduate studies in the non-science faculties, which he suggests are freer than the scientific and technical faculties from the restricting effects of the demand for highly trained professional artisans and research workers, does not believe that research and teaching staffs should be separated, but that more guidance could be offered at the undergraduate stage and that the quality of research rests fundamentally on the quality of the undergraduate schools. He stresses the im- portance of travel and of minimizing professorial administration. Dealing with postgraduate studies in science and engineering, Prof. L. H. Martin also deprecates the tendency in Australia to favour complete segregation of research from teaching and, in particular, to subjugate research and its proper function to the university's responsibility for postgraduate training. In the absence of a background of tradition, the Australian university, he urges, must foster close association with the community which supports it, and here the technological departments have a special responsibility. Prof. Martin is concerned that the average quality of science students has deteriorated in the post-war years. First-class talent is becoming rare among science graduates. There is evidence in Melbourne that the number of Ph.D. candidates in science is likely to decrease, and in 1954 there was only one applicant for the most prized travelling scholarship in science offered within member countries of the British Commonwealth. $\mathrm{He}$ also believes that lack of finance, including inadequate salaries, is the fundamental cause of frustration in Australian universities.

\section{UNIVERSITY EDUCATION IN HUNGARY}

A $T$ the eighth university conference organized by A the International Association of University Professors and Lecturers and held in Vienna during September 9-14, 1954, Prof. L. Tamas, of the University of Budapest, described the development of university education in Hungary since 1945.

In recent years there has been a vigorous expansion in university education. In the year 1937-38 there were 12,000 students in the universities and the grandes écoles (13 per 10,000 population); in the year 1953-54 there were more than 53,000 such students (56 per 10,000 population). There were 473 foreign students in Hungary, and, with the exception of Australia, all quarters of the world were represented. In 1938-39 Hungary had 16 universities and grandes écoles with 37 faculties; to-day there are 33 universities and grandes écoles with 56 faculties. In 1952 and 1953 the State budget had given almost 260 million forints to the construction of new universities and the expansion of the older institutions.

Prof. Tamas also spoke of student conditions. In former years, the children of workmen and peasants, who formed the greater part of the country's population, represented $3 \frac{1}{2}-4$ per cent of the total number of students; to-day they constitute more than one. half of the total student body. Women students, to whom all careers are now open, represented 13 per cent of students in 1937-38. To-day the proportion is $26 \frac{1}{2}$ per cent. A noticeable change has taken place in the subjects read. Previously, more than one-half of university students and one-third of the total number of students followed courses in the faculty of law, while those who undertook technical and scientific studies formed much the smallest group. To-day this proportion is reversed : 47 per cent of the total number of students are registered in technical and science faculties, while 3 per cent only follow law courses.

A great deal of State assistance is given to university students. More than three-quarters pay no fees, the remainder pay minimum terminal charges. There are no charges for laboratory-work or examinations. 
More than 90 per cent of the students benefit regularly from bursary grants, 17,000 reside in student hostels and 24,000 feed in student canteens. There is medical and social aid.

Prof. Tamas discussed curriculum reforms which have been introduced and brought closer in line with the country's economic and practical needs, and the extent of the advanced and research work undertaken in the Hungarian universities.

\section{RED FOX IN THE UNITED STATES}

A $N$ evaluation of the red fox in the United States A has been made by Thomas G. Scott, on behalf of the Illinois Natural History Survey*, which suggests that the fox has shown no sign of declining in numbers and that it has unusual capabilities for survival despite keen competition; the opening-up of forest lands and the reduction or elimination of wolves and coyotes seem to favour foxes. Some reports on rabies outbreaks in the eastern United States indicate that the fox is fully capable of reaching population-levels which are too high to serve its own interests.

The role of the red fox as a predator appears to be the most important of the various factors affecting the economic position of this animal. It tends to take the foods which are most readily available, and thus its diet varies immensely both with the season and the environment. The diet does not reflect precise, automatic adjustments to changes in population-levels of specific prey. For example, during the spring and summer, when prey such as rabbits, mice and birds are found in increasing numbers, the frequency of occurrence of these items in the fox's diet declines where acceptable fleshy fruits and insects are available. Thus it would be unwise to claim or expect an increase in numbers of prey species in response solely to the reduction or elimination of red foxes. A large-scale experiment with the reduction of a fox population as a means of increasing a pheasant population in New York State resulted in the conclusion that "despite reducing the fox population to a very low level, fox control on the Seneca County area did not increase pheasant abundance appreciably and certainly not to a degree commensurate with the cost". Though foxes unquestionably prey upon vulnerably situated poultry, and to a lesser extent on small pigs and lambs, it seems that poultry losses result largely from failure of owners to follow recommended poultry-husbandry practices.

Foxes are among the most important vectors of rabies in the United States, and herein probably lies their greatest nuisance. People living in an area where rabies has been reported experience great mental distress, and may even have to suffer the physical discomfort of Pasteur treatment if attacked. It is certain that losses occur among livestock infected through the bites of rabid foxes. When rabies breaks out in a locality of high fox population, the disease is likely to continue until the foxes in that general area are virtually exterminated; this may take from one to three years.

The most desirable method known for bringing rabies outbreaks among foxes under control has

* Natural History Survey Division of the State of Illinois. Biological Notes No. 35: An Evaluation of the Red Fox. By Thomas Education, 1955.) proved to be population reduction by means of organized trapping; but whether the several million dollars that has been paid out during the past twenty years on fox bounties has been money well spent is a question open to doubt. Experience in Pennsylvania indicates "that probably 50 per cent or more of the mammalian predators (red fox, gray fox, and weasel) would have been killed regardless of the bounty". The bounty system cannot be directed efficiently toward the reduction of specific, excessive fox populations because the administrative areas in which funds are approved for bounties seldom conform with the particular areas needing attention. The economic demand for red fox pelts is at present very low. The sport of fox-hunting contributes to the reduction of fox populations, and the survey, which is well illustrated, discusses the ethical and resthetic values involved in this sport.

\section{STIMULATION OF YIELD FROM RUBBER TREES}

A GOOD deal of work has been done at the A Rubber Research Institute of Malaya, both before the Second World War and, more recently, on the stimulation of yield in the rubber tree Hevea brasiliensis by applications of vegetable oils (for example, palm oil) and various synthetic substances, and several aspects of this are described by E. D. C. Baptist and P. de Jonge in the Journal of the Institute $(14,355 ; 1955)$. A brief historical review is given of methods used for stimulating the latex yield of rubber trees, and experiments are described in which vegetable oils applied to lightly scraped bark below the tapping-cut resulted in large increases in yield.

The results of these early experiments provided a clear picture of the reaction of the tree to yield stimulation and led to the development and commercial use of yield stimulants. Similar application of a number of synthetic growth substances in an oil vehicle has also resulted in increases in yield and in the thickness of renewed bark above the cut. Repeated applications of the treatments at sixmonthly intervals over a period of three years have not resulted in an increased incidence of 'dry' trees; but the yield response is found to decrease with each successive treatment. Monthly treatment with yield stimulants of renewing bark just above the tapping: cut has also resulted in greatly increased yields and in an increase in bark thickness; the latter is confined to the non-latex-bearing tissues of the outer bark. A study has been made of the effects of 2,4-dichlorophenoxyacetic acid (2,4-D) and 2,4,5trichlorophenoxyacetic acid $(2,4,5-T)$ on the rubber extraction area of the bark on tapping, the incidence of brown bast, rate and duration of latex flow, anatomical structure of the bark, and the properties of latex and dry rubber.

The response of the rubber tree to yield stimulants is shown to be influenced by the condition of the bark, the type of planting material, the tapping system, the composition and method of application of the mixture. An extension of the area of rubber extraction in the bark of trees in normal tapping as a result of treatment with yield stimulant has been demonstrated experimentally and is thought to account for the increased yields obtained and for the low incidence of brown bast after repeated treat. 